\title{
DIGITIZATION OF THE CONSTRUCTION INDUSTRY IN THE Czech Republic
}

\author{
Lukas Rudl*1 \\ ${ }^{1}$ Czech Technical University in Prague, Faculty of Civil Engineering, Thakurova 7, Prague 6 - Dejvice, \\ 166 29, Czech Republic, lukas.rudl@fsv.cvut.cz, https://orcid.org/0000-0003-2860-9806
}

\begin{abstract}
The work is focused on the issue of innovation in construction, which is associated with the gradual digitization of the entire sector to streamline work processes, save time and costs. The work addresses in more detail the issue of BIM implementation and the overall transformation of the construction industry based on the approved innovation strategy of the construction industry in the Czech Republic 2019-2030. From the point of view of introducing digitization into the construction industry, construction companies in the Czech Republic receive support mainly from subsidy programs, thanks to which construction companies can obtain a contribution for the purchase of new software and hardware solutions. The BIM method is analyzed in more detail from the point of view of implementation in a construction company and the implementation process itself is divided into several steps. Currently, the issue of BIM implementation is a very current topic, especially regarding the impending obligation to award above-limit public contracts in the Czech Republic for construction work, including contracts for related pre-project and project services in the above-limit regime using the BIM method.
\end{abstract}

\section{Keywords}

Digitization, innovation, BIM, construction company, BIM implementation

\section{JEL Classification}

O31 Innovation and Invention: Processes and Incentives

O38 Technological Change: Government Policy

DOI: https://doi.org/10.14311/bit.2021.01.09

Editorial information: journal Business \& IT, ISSN 2570-7434, CreativeCommons license (c) (i) published by CTU in Prague, 2021, http://bit.fsv.cvut.cz/ 


\section{Process innovation}

The basis of every innovation is invention, its main and characteristic feature are new ideas leading to new ideas. The invention itself is thus associated with creativity, which leads to the practical creation of values. The result of creative invention is subsequent innovation [1].

Innovation is a process that starts with invention and develops in several stages until the actual implementation. Innovation is linked to advanced economies, which, through innovation activities, increase their competitiveness and economic growth, which forms the basis for [2]:

- creation of new businesses;

- new jobs, higher productivity;

- reducing product prices;

- new needs.

According to the definition of the European Union, innovation generally means a change to the development and production of products, processes, and services. The aim of support from the European Union is to create new products and services from innovative ideas that generate new jobs and economic growth. At the same time, the Union is addressing the main concerns of citizens on climate change, energy efficiency and a healthy lifestyle. Among the main goals of innovation in terms of a long-term strategy is to make Europe a world scientific power, to intensify public-private partnerships and to remove obstacles to innovation [3]. Within the framework of the national innovation strategy from 2004, the Czech Republic defines innovation as a process that begins with an idea or idea, goes through several stages of development and is subsequently implemented. The main objective is to increase competitiveness in a dynamic market [4]. The basic division of innovations is technical and non-technical. Technical innovations are associated with the introduction of new products or significant technological improvements to existing products and technologies for production.

\section{Product innovation}

Within manufacturing companies, it is a matter of launching a completely new or significantly improved product. Improvement means a significant improvement of technical parameters or parts of the product. It can also be a change of material. In the services sector, these are mainly new services or changes to existing services [5].

\section{Process innovation}

The innovation process is associated with the implementation of a significant change in the field of production technology and supply methods. These are main changes to the hardware, software and processes using these devices. The result of process innovations can be a reduction in production costs due to new technological processes, which lead to less scrap and reduced material consumption. Lower costs can bring more variability when choosing a marketing strategy. 


\section{Innovation barriers}

However, each innovation also has its limits, which are difficult to exceed, and before starting the innovation process, it is necessary to specify the risks and costs for the innovation process. The most common obstacles during innovation include:

- Business - technology information may not be complete, insufficient knowledge of customer needs, within the company is not sufficiently qualified staff.

- Economic - high financial demands of innovation, inability securing funds.

- Others - complex process of obtaining licenses and rights, legal aspects, political environment

In every innovation process, if an obstacle is found, it is necessary to look for possibilities and solutions. In case of economic obstacles, the use of one of the subsidy programs is offered. At present, as of February 2021, Call VIII (innovation project) is underway within the Agency for Entrepreneurship and Innovation [6].

\section{Innovation management}

Innovation is a process that can be defined as the introduction of a new or significant improvement in an existing management process, such as a change in software or an improvement in hardware. All innovations should have a defined expected benefit for society after implementation, such as a reduction in labor costs, an improvement in working conditions or a reduction in operating costs [6].

The innovation process can also be defined as an activity that is necessary to maintain the competitiveness and continuous growth of the organization. Innovation should therefore include the following processes:

- Survey

- Selective selection

- Resources

- Implementation of innovation

- Implementation of the solution

- Evaluation
- analyze threats and opportunities from your surroundings

- select relevant signals from the survey for a more detailed survey

- resources need to be secured for the selected innovation opportunity

- preparation after launch, one of the most difficult parts

- implementation or introduction to the market

- monitoring and further development

Whatever the type of innovation, it should always go through all the processes. In the case of inhouse innovation, a responsible person should be identified for each innovation, who is most often the bearer of the original idea and has a positive attitude towards the innovation. When it comes to innovations in certain departments of a company, there is often a guarantor of the innovation, which is most often a manager. One of the most important points before the start of innovation is gaining the support of the company's top management, which also decides on the resources that will be allocated to innovation [7]. 


\section{Innovation strategy of the construction industry in the Czech Republic 2019- 2030}

One of the main goals of the innovation strategy is to accelerate construction management, which by 2019 is on the international ranking of the overall construction management process prepared by the World Bank Group [8] in 157th place out of 186. In comparison with neighboring countries, Slovakia is similar. is in 146th place. All other neighbors are ranked 50th. In our country, the entire permitting process takes 246 days, according to the statistics used for the international comparison. E.g., in neighboring Germany, it is only 126 days [8].

Other goals include the completion of the backbone network of transport infrastructure, which should be helped by Act No. 403/2020 Coll. on accelerated construction of transport infrastructure, the so-called "line law", which is now effective from 1.1.2021. The main benefit of this law is the possibility to start construction before the expropriation process is completed. Another significant novelty within the amendment to the Act is the obligation of the authorities concerned to issue a binding opinion without undue delay no later than 30 days of its request, with the possibility of extension for another 30 days if an on-site inspection is required. If the authorities concerned do not comply with the deadlines, the so-called fiction of consent begins, and the opinion is considered to be in agreement and without conditions.

The main goal of the strategy from the point of view of construction digitization is to simplify and speed up the administrative processes of construction management and spatial planning, which should be possible digitally. The main points of digitization include the introduction of a unified IT system for building authorities, which will have clearly defined tasks, simplification of procurement, interactive forms, online information on the status of proceedings for all participants, electronic file management, standardization of project documentation format. Fulfillment of all objectives should lead to transparency of proceedings of building authorities and central storage of documentation. The planned date for the introduction of systems for the digitization of building management and spatial planning is 1.7.2023 [9].

\section{Innovation programs in the Czech Republic}

At present, as of February 2021, the Operational Program Enterprise, and Innovation for Competitiveness (OPPIK), which was intended for the subsidy period 2014-2020 and included four areas of support, is still active in the Czech Republic.

- development of research and development,

- business support for small and medium-sized enterprises,

- more efficient energy management,

- development of information and communication technologies.

As of February 2021, three subsidy programs are open for the construction industry (energy savings, technology 4.0 and energy savings in heat supply systems) and for one (ICT and shared services - digital enterprise) a call is expected in June 2021. The number of subsidies is divided mainly by the size of the company, which is related to the number of employees. Each subsidy specifies the supported activities, what it is intended for, how large the enterprise is intended for and what the minimum and maximum amount of the subsidy is [10]. 
For the years 2021 to 2027, an operational program of technology and applications for competitiveness (OP TAK) is created on the basis of the approved European budget.

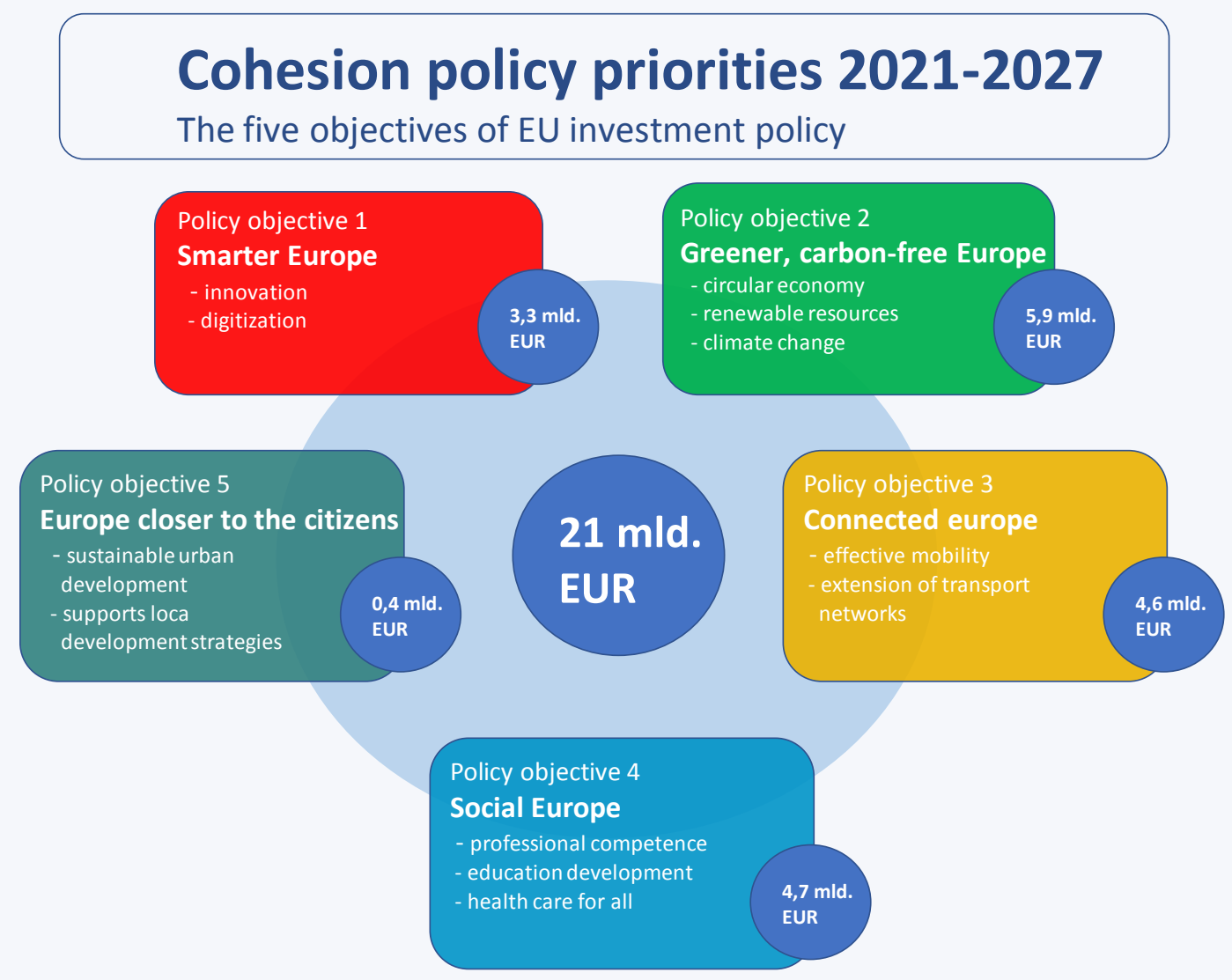

Figure 1: Structure of OP TAK focus (source: API [11])

The first subsidy programs should open in the summer of 2021 and will be intended for all small and medium-sized enterprises, unless the previous OPPIK operational program is extended due to extraordinary measures associated mainly with the covid-19 pandemic, which made it impossible to submit applications properly. Large companies will only receive support in the areas of research, innovation, energy saving and the use of renewable resources. A total of CZK 82 billion is ready for distribution for the program. The program will now also be available to businesses in the capital [12].

\section{Areas of digitization of construction companies}

Currently, most digitization in the world of construction focuses mainly on the introduction of the BIM method, which brings many changes, including digitization to the traditional construction process. As of February 2021, 27 pilot projects related to the BIM method have been published on the website dedicated to the BIM concept in the Czech Republic (www.koncepcebim.cz). On the BIMfo website (www.bimfo.cz), which deals with news about the introduction of BIM in the Czech Republic and tries to bring readers practical experience from implemented and planned projects, based on cooperation with project developers. As of February 2021, this page contains a link to 173 companies that are already actively using BIM. These are mainly developers, construction companies, design offices and other users. In the case of construction, the largest involvement in the Czech Republic can be observed regarding digitization and the BIM method in the construction companies Skanska, Strabag, VCES, which are also listed in the list of companies actively using the BIM method. 
On 1 August 2019, an inter-ministerial working group for the introduction of the BIM method in the Czech Republic was established, which aimed to ensure coordination and communication of the approved government concept for the introduction of the BIM method in the Czech Republic between public, private and academic entities. As of January 20, 2021, a working committee for the introduction of the BIM method in the Czech Republic was established within the Executive Committee for the Information Concept of the Czech Republic, which now includes the BIM working group and builds on its work to date. The benefit of this change should be greater coordination in the implementation of the BIM method with the process of digitizing public agendas.

Construction companies need to be understood as a whole consisting of several organizational units that can be interconnected, and their processes need to be constantly monitored and streamlined. In the case of process innovation and the introduction of new software solutions, the biggest trend today is the use of available commercial solutions, which pose minimal risk compared to developing your own software solutions, which can be more costly and time consuming. In the case of the digitization of a construction company, three key points need to be addressed [13]:

- data digitization;

- process automation;

- connectivity.

All three of these points are particularly important in terms of implementing the BIM method. The actual digitization of data is mainly represented by the BIM model of the building. Communication and data transfer within the construction between the investor, supplier and designer should take place in a common data environment where all communication processes are fixed. All processes of documentation submission, commenting and approval should thus show automation based on predefined parameters. For all communication in the online environment, connectivity is needed, which is also used during construction, when the inspection of the work and any discrepancies can be documented and immediately sent to the responsible persons directly on the construction site, using a tablet with internet connection.

According to an analysis by ROLAND BERGER [13], managing the transition of construction companies to the digital world is key to increasing productivity and maintaining competitiveness. In the Czech Republic, the biggest innovations and digitizations can be observed in the construction industry, especially in multinational companies, which take over many processes from abroad.

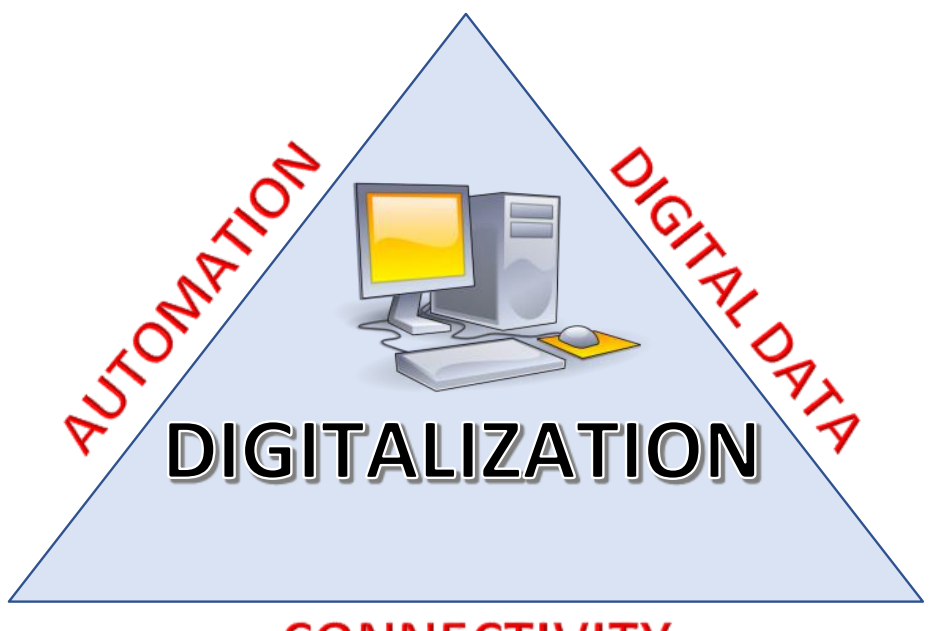

CONNECTIVITY

Figure 2: The main points of digitalization of society (source: author)

Digitization in society should be understood mainly as a change of existing habits in set processes and to determine what benefits digitization should bring. 


\section{Implementation of BIM in a construction company}

Due to the current state of implementation of BIM in the public sector, requirements are gradually being created for the implementation of documentation in the BIM environment and from the private sector, which is gradually gaining experience and recognizing possible benefits. A strategic advantage in terms of competitiveness for construction companies will be mastering the processes associated with the management of projects that are designed in a BIM environment. For construction companies themselves, the introduction of BIM is a new discipline, and this step is important to think carefully and analyze the possibilities. In the absence of knowledge of BIM issues, it is advisable to turn to a professional company offering consulting services with implementation and thus reduce the risk associated with misunderstanding of BIM processes and increased implementation costs.

The implementation itself can be divided into several steps:

- identification of existing work processes;

- identification of the data exchange process;

- identification of current hardware equipment;

- set goals;

- identify risks;

- build a BIM team;

- find a suitable partner for implementation;

- software selection;

- team training;

- implementation into management processes;

- pilot project.

At the beginning before the actual implementation, the company needs to support especially the top management of the company and its acquaintance with the issue of BIM, all impacts on the company's organization and possible risks.

Before starting the implementation, it is necessary to perform an analysis of the current state of management in the company, setting up work processes and available hardware equipment. Based on this information, a preliminary financial plan for implementation is drawn up, what are the benefits and goals for the company and what are the risks associated with the implementation. Companies are often looking for barriers to the introduction of BIM but are no longer looking for a vision of possible success.

One of the most fundamental topics in the beginning is the costs associated with implementation. Small companies see in implementation a large amount of costs, which is often associated with insufficient hardware equipment. During the implementation process, additional costs often arise in the form of updates, additional training, software upgrades and continuous training of employees due to the rapidly evolving BIM environment. The implementation of BIM can thus be a great source of costs, if we add the cost of the employee who deals with the implementation, there is often a personnel problem with respect to the human resources of small companies. The advantage of implementing BIM in a small company is often the versatility of employees and flexible response to changes compared to the plan. Large companies, on the other hand, often have sufficient financial and human resources to release. In the initial phase of BIM implementation within contracts, deployment can be expected especially for large contracts. Thus, small companies dealing with many small contracts are unlikely to be able to obtain a pilot project. 
There are also risks associated with the implementation, which stem mainly from a misunderstanding of BIM, which can cause a negative attitude of employees or even top management, which can lead to a loss of support. In the case of entrusting the implementation of BIM to one of the company's employees, who ideally becomes the head of BIM, it is often necessary to consider the low level of experience, which can cause errors and incur additional costs.

Within the company, it is necessary to involve especially capable people who are interested in BIM, and management must understand the implementation of BIM as an investment in the future, which needs to be made well in advance to gain a competitive advantage.

When deciding, it is important to choose whether the company has employees with the ability to implement and further develop it or whether outsourcing is a better option. In the case of outsourcing, there should be a reduction in the risks associated with the ignorance of employees and at the same time a reduction in implementation time. On the other hand, outsourcing carries an increase in costs. The cost side can be reduced, for example, by obtaining a subsidy from the state, which mainly supports small and medium-sized enterprises.

The selection of the most appropriate BIM software tool should be accompanied by a multi-criteria evaluation, which should not be based solely on price. One of the important aspects of the selection is also the continuity with the company's equipment to avoid additional costs for changing equipment. All these costs should be included in the initial financial plan.

Overall, the implementation of BIM should be slower without high expectations due to the lack of standards and the legal environment. The objectives should not be too ambitious given the relatively complex issue, which requires time for training and deepening of practical knowledge. The ideal situation is to provide a pilot project on which employees could try out the established BIM management processes in practice and identify imperfections.

\section{BIM issues from practice}

The introduction of the BIM method in companies will gradually grow with increasing tenders in which projects will be processed using the BIM method and there will be a requirement for further construction management in a common data environment. At the same time, it can be assumed that to obtain orders processed by the BIM method, it will also be necessary to submit references from projects implemented by the BIM method. The key point for maintaining competitiveness will be to obtain this reference for companies and to have mastered the methods of managing BIM projects. Large construction companies that also have their own development can, for example, gain experience in implementing their own development project, which will be processed using the BIM method. In this case, however, the question is whether companies will want to sacrifice money or possibly increase the price of real estate offered, as the processing of documentation using the BIM method brings higher costs compared to standard 2D documentation. On the other hand, in addition to the necessary reference, it can also be advantageous to test new systems and methods for construction management using BIM and to gain the practical experience of the workers themselves.

At present, the biggest advantage on the market is mainly multinational companies, which have branches in Western and Northern Europe, where orders are already routinely realized using the BIM method. These companies thus draw the necessary data from these countries and take over the created management models. 


\section{Conclusion}

Companies that want to remain competitive today should not wait for the introduction of innovations associated with digitization and especially with the BIM method, given that the whole process of selecting the appropriate software and hardware solution and implementation is relatively lengthy and cannot be done from day to day. Especially for small and medium-sized enterprises, which do not have sufficient capital available for innovation and digitization, it is possible to use, for example, a subsidy program led by the Ministry of Industry and Trade. A new OP TAK operational program has been created for the years 2021-2027, with the help of which small and medium-sized enterprises will be able to obtain a subsidy that will cover up to $45 \%$ of the costs associated with digitization. Large companies can receive a subsidy of up to $25 \%$ of costs. In practice, the key point will be whether the BIM for public procurement in the above-limit regime will be introduced in 2023. Other positively received innovations in the construction industry include the online construction diary, which has been the obligation to keep an above-limit regime for constructions since 1 January 2021, which was to bring greater transparency and controllability of orders. Overall, we can expect the gradual digitization of the entire construction industry and all its processes, which concern the entire life cycle of the construction. Thanks to the digitization of buildings and the creation of digital twins, the state will be able to manage the operation of its properties more efficiently than before.

\section{References}

[1] Švejda, Pavel a kolektiv, a. Inovační podnikání. Praha: Asociace inovačního podnikání, 2007. 978-80903153-6-5.

[2] Veber, Jaromír a kolektiv, a. Management inovací. Praha: Management Press, 2016. 9788072614233.

[3] Zagamé, P. The "Innovation Union" - turning ideas into jobs, green growth and social progress. [Online] 6. ř́jen 2010. https://ec.europa.eu/commission/presscorner/detail/en/IP_10_1288.

[4] Jasanský, Jaroslav. Národní inovační strategie České republiky. Ministerstvo průmyslu a obchodu. [Online] 23. leden 2006. [Citace: 21. leden 2021.] https://www.mpo.cz/dokument11662.html.

[5] Miloslav, Synek. Manažerská ekonomika, 5., aktualizované a doplněné vydání. Praha : Grada Publishing, 2011. 978-80-247-3494-1.

[6] Inovace - Výzva VIII (inovační projekt). Agentura pro podnikání a inovace. [Online] [Citace: 2. 2 2021.] https://www.agentura-api.org/cs/programy-podpory/inovace/inovace-vyzva-viii-inovacni-projekt/.

[7] OECD. Oslo Manual: Guidelines for Collecting and Interpreting Innovation Data. Paris : OECD Publishing, 2005. Sv. 3rd ed. 92-64-01308-3.

[8] The World Bank Group. DOINGBUSINESS. [Online] The World Bank Group, 2021. [Citace: 19. únor 2021.] https://www.doingbusiness.org/en/data/exploretopics/dealing-with-construction-permits.

[9] Projekt - Digitalizace stavebního řízení. Ministerstvo pro místní rozvoj ČR. [Online] Ministerstvo pro místní rozvoj ČR, 2020. [Citace: 18. únor 2021.] https://www.mmr.cz/cs/ministerstvo/stavebnipravo/digitalizace-stavebniho-rizeni-v-cr/projekt-digitalizace-stavebniho-rizeni.

[10] Dotační programy. OPPK. [Online] enovation s.r.o., 2020. [Citace: 18. únor 2021.] https://www.oppik.cz/dotacni-programy.

[11] OP TAK. agentura API. [Online] [Citace: 19. únor 2021.] https://www.agentura-api.org/cs/op-tak/.

[12] Připravované dotační programy. OPTAK. [Online] INIZIO Internet Media s.r.o., 2021. [Citace: 19. únor 2021.] https://www.dotace-optak.cz/dotacni-programy/.

[13] Roland Berger. Roland Berger. [Online] 2016. [Citace: 30. září 2020.] https://www.rolandberger.com/en/Publications/Digitization-of-the-construction-industry.html.

\section{Acknowledgement}

This work was supported by the Grant Agency of the Czech Technical University in Prague, grant No. SGS20/101/OHK1/2T/11. 